\title{
役畜の選抜に関する研究の動向
}

\author{
岡 本 正 幹 \\ (九州大学農学部)
}

The current of studies in the selection of draft animals

\section{Seikan Oкамото}

(Faculty of Agriculture, Kyushu University)

\section{緒言}

最近用畜の增殖が急速に進んでいるので，相対的には 役畜のウェイトが次第に低下して行く傾向にあるけれぞ も, それでも頭数(家音策位)から見れば役畜の飼養が日 本畜産の中核となつているととはたしかである。従つて 畜力利用に関する理論的ならびに実際的研究は, 従来か らきわめて活発であつて，世界の水準を抜了ものがある といつても過言ではなからう。近年岡部 $(1954)^{1)}(1956)^{2)}$ によつて相ついで書かれた二篇の総説は，よくこの事実 を証明する。とてろで畜力利用研究会の結成以来，ての 方面の研究が一段と活発化したために，その後において もかなり重要な成果の発表があつたてとは喜ばしいとと である。とてにその全般に亘つては述べるととは，いさ さか屋上に屋を重㸚る感があり，かつまたわずかの紙面 では困難でもあるから，問題を選抜の面だけにしぽつて 最近の動向を紹介したい。

\section{役能力と体型との関係}

役能力の検定法については，前記岡部の総説の外に， 羽部 $(1543)^{3)}(1946)^{4)}$ の詳細な紹介があり, その後石崎 $(1956)^{5)}$ の報告もある。本来役能力には物理的要因の外 に，生理的あるいは心理的要因も関係しているので，乙 れらの要因を分析する必要があるが，あまりてれにてだ わると，数值をもつて表現するてとが不可能となつて， 体型との関係を論ずるには不都合である。たとえば石原 等 $(1952)^{5)}$ が和牛の役能力検定に用いた方法は, 率引力 ・態度・調教及び馴致・所要時間・歩様・疲労程度・回 復状態などに分けて判定するもので, 構想としては興味 深いものであるが，実施は煩雑であり，かつ数量をもつ て評価するのに不適当な項目が多数含まれているので, 判定に当つて多少とも主観の介入する余地もあり，その 実用佂值については問題が多い。その著者等の一部であ 万石原・吉田 $(1952)^{7)} も$, その後実施した和牛の役用体
型に関する研究においては, 最大牽引力のみを取上げて 体型との関係を検討している。もつとも数量をもつて正 確に評価できるとすれば，最大率引力以外にも考慮す心゙ き要因はあるわけで，石崎等 $(1949)^{8)}(1951)^{9)}(1954)^{10)}$ 11)は馬の大きさと役力との関係を追究した一連の研究に おいて, 最大荷重（最大牽引力に相当）・歩速・耕起面 積（仕事量に相当）なぞを一括して考慮している。また 岡本等 $\left.(1955)^{12}\right)(1956)^{13)}$ は最大牽引力の外に, 歩速と最 大仕事率を考虑して褐毛和牛の体型との関係を論じてい る。なおこの外に，内容については後に紹介するが，黒 肥地等 $\left.(1954)^{14}\right)$ が耐暑性を加えているのも興味ある方法 であろう。

役畜の最大率引力が体重によつて強了影響されるてと は，物理学的常識によつても容易に推定されるが，前記 の石原等及び石崎等の研究は，てれを実験的に証明して いる。一方体重は体型各部の積算効果であると考元られ るので，体重と各部位の測定值との間には，多少の差は あつても，概してかなりの相関がある。従つて最大率引 力と各部位の測定值との間に，概して有意の相関がある ことも，当然予想されるが，石原等及び石崎等の研究は ての点についても実験的に証明している。とてろで農業 経営の規模や内容を考察すると, 体重によつて代表され る役畜の体格は，大きければ大きい程よいというわけの ものではなく, 経済効果の立場からは, 体格を大きくし ないで力のあるものを選抜することが望ましいわけであ る。岡本等の研究は強くこの点を考慮して, 体重を一定 とした場合の体型のあり方を検討する意図のもとに，供 武牛の選定に当つて体重の変異を限定し,さらに最大牽 引力と各部位との相関を検討する際には，体重の影響を 除いた偏相関を重要視している。その成績を同しく和牛 を材料とした石原等の成績に比較すると，材料において 石原等は黒毛，岡本等は褐毛を用い，率引方法において 石原等は水平旁引，岡本等は角度言引を用いているので その点に多少の差はあるかもしれないが，両者の結論に 
はかなりの差が見られる。すなわち，体積を重要視して いる点は一致しているが, 前躯について石原等が幅より も深さを重要視しているのに対し，岡本等は深さよりも 幅を重要視しているし, 前者が前勝体型を望ましいもの としているのに対し，後者はそれにてだわるのは適当で ないとしている。腿について前者は広さと厚さを重要視 しているが, 後者は広さと深さを重要視している。また 前者は飛節が高了，管が太いとと走望んでいるのに対し， 後者はそのいずれをも全く重要視していない。要するに 石原等は従来観念的に考光られておつた役用体型をその まま是認する態度をとつているのに，岡本等はかなりそ れを批判し，観念を是正する必要性を論じている。

率引歩速と体型との関係については，馬における前記 石崎等の研究と, 牛における前記岡本等の研究が注目さ れる。石崎等は, 体重の1/10抵抗の帝引試験では体重の 大小は歩速と関係がないけれども，犁耕の場合には体重 の大きい方がいくらか有利であると述べている。一方岡 本等は体重を $450 \pm 75 \mathrm{~kg}$ に限定した材料についてではあ るが，体重と重率引（体重の25 30\%抵抗）の歩速との 間には有意の相関を認めていない。もつとも石崎等は体 重の大小に応じて別の品種を用いているので, 品種差が 介入する可能性も考えられる。要するに体重と歩速との 間にはこう高い相関はないものと考えてよかろう。岡本 等は重牽引の歩速と体型各部位との相関を求めた結果, 彼等の検討した範囲では，上腿及び下腿の深さ（撸と飛 節との垂直距離) と管の細さが歩速を速める要因であつ て, その他の部位については有意性を見出していない。

仕事量と体型との関係については, 石崎等は馬におい て体重・体高・胸囲・管囲・体長・腰幅などと耕起面積 との関係を検討して，馬格の大きい方が仕事量が多いて とを立証している。なにしろ彼等の材料は体重の変異が 著しいので，てのような結果は常識的にも推定されると ころである。一方岡本等は体重の変異を限定した牛にお いて，体型各部の測定值と最大仕事率（馬力を単位とす る）との相関を求め，体幅とくに前躯の幅・腿幅・腿深 などは最大仕事率と正の相関があるが，飛節高や管囲は それと負の相関があるととを指摘している。

石原等 $(1956)^{15}$ ) は最大牽引力と蹄との関係を検討し, 大き〈形のよい蹄の重要性を指摘している。しかし体重 との関連を考慮していないので，その点に多少問題があ る。

\section{役能力に関する品種の比較}

さきに紹介じた石崎等の一連の研究は, 馬の大きさと 役力との関係を主目的としたものではあるが，材料とし
て朝鮮済州島馬, 北海道和種系統馬, 中間種馬などを用 いているので, 別の角度からは品種の比較試験とも見ら れる。しかし品種間の体重差が著しいので, 結果として役 力は体重の序列に準じて中間種馬 > 北海道和種系統馬> 朝鮮済州島馬の順となつている。石崎等 $(1956)^{16)}$ は別に 拢及び騾の役力についても比較試験を行つている。この 報告で著者等は従来行つてきた馬に関する成績を加え， 然も同し程度の体重をもつものを比較検討しているので 品種の比較としては例数に乏しいけれども，か广り興味 深いものがある。その成績によると, 持久力においては 北海道和種系統馬が最もすぐれ, 最大晚曳力においては 驉・騾ともに馬よりもすぐれ, 駄載力においては驟がと くにすぐれているらしい。ドイッで KRÜGER u. SEEFELDT $\left.(1955)^{17}\right)$ が行つている馬の役力比較試験は石崎等の 研究と類似のもので, 冷血種・半血種・温血種・小格馬 ポニーなどの索引力を比較して, 索引力は体重に準じて ての通りの序列で低下すると報告している。また原著を みていないのではつきりしないが，チエッコの SAGHIN et al. (1955) ${ }^{18)}$ は重種・眭種・及びその雑種を比較し, 1 ha 当りの各種農耕作業の合計所要時間からみると, 雑種 が有利であるといつているし，ポーランドの PRAWOCHNSKI and PIOTRASZEWSKI (1953) $\left.{ }^{19}\right)(1955)^{20)}$ は馬の各品 種の最大索引力を体重に対する比率によつて比較し, 絶 対的にはもちん重種が強いが，ての比率ではポニーが強 々, 軽種が最も劣るといい, 一般的にはての比率と生体 重との間に有意の逆相関があるともいつている。

一方牛については WENGER (1939) 21$)$ がスイスのブラ ウンスイスとシンメンタールを比較した報告がある。て れによると, 索引力は後者が強了, 歩速は前者が速いが 仕事率では後者がややすぐれている。もつとも体重差を 考虑すれば大体同じである。日本でもとの種の研究は最 近かなり見られる。前記石原等(1952) $\left.{ }^{9}\right)$ はその創案によ る農用索引能力検定法により, 黒毛和種・褐毛和種・無 角和種・ホルスタイン種など党比較し, 黑毛と褐毛とは 能力に大差なく，無角及びホルスタインはこれらに劣る といつている。一方小田等 $\left.(1953)^{22}\right)$ は見島牛・黒毛和種 ・褐毛和種・無角和種などの最大尧引力を比較して, 褐 毛>黒毛 > 無角>見島の序列であつたと報告している。 もつともこの試験は材料の選定に多少問題があるように も思われる。別に見島牛については石原・吉田(1956) ${ }^{23)}$ が黒毛和種との役力比較試験を行つた例もある。それに よると見島牛の牽引力は, 絶対的には黒毛和種に劣るが, 体重に対する比率としてはむしろ勝つている。岡本等 $(1954)^{24)}(1956)^{25)}$ は, 他の目的のために行われた研究で はあるが，たまたま褐毛和種と黒毛和種とに体重の $12 \%$ 
抵抗の欛を史かせた持久牽引試験を行つている。その結 果をいま比較すると, 褐毛の方がいくらか持久力がある ととがわかる。ただしとれる材料に乏しい。異色ある研 究としては, さきに紹介した黒肥地等 $(1954)^{14)}$ が褐毛和 種と黒毛和種との炎天下に和ける役能力を比較したもの がある。これによると褐毛の方がややすぐれているとと になつている。以上の各試験はいずれも品種の比較とし ては例数に乏しいので, 䈌密には有意差を論ずることが できない程度であうう。これに関連して, 既にしばしば 引用した石原等 $\left.(1952)^{7}\right)$ 及び岡本等 $(1955)^{12)}$ の研究は, 例数が多いだけに比較できれば幸であるが，石原等の研 究に統計資料の提示がないのが惜しい。

つぎにまだ公表されていないようであるが，興味ある 研究として富永等(1957) 26 )の黒毛和種・ホルスタイン種 その $\mathrm{F}_{1}$, 及び日本短角種に関する役能力比較試 験があ る。とのうち $F_{1}$ の問題はとくに注目されるが, 役力は黒 毛とホルスタインとの中間であるというととである。例 数は少いが, 公表が期待される。なおホルスタイン種に ふれたので, 乳牛の役能力にも言及すると, 野田・中野 $\left.(1951)^{27}\right)(1953)^{28)}$ の一連の研究が注目される。もつとも 乳牛の役能力となると,単に役能力だけの問題ではなく, 産乳能力えの影響をも充分に考虑しなければならない。 この方面の研究はかなり多数あるが, 本稿の趣旨からは 逸脱するてとになるので，ててではふれない。

要するに品種の特徴としては体格の大小が顕著である のに，役力あるいは役能力はこれと密接に関連している ので，相互関係はきわめて微妙である。いまのとてろて れらを分析した研究は少いが, 品種の特徽としては体格 以外の要因も多数存在するはずであるから, 今後の方向 としては体格以外の要因と役能力との関係をも, 充分に 考虑して追究して行く必要があろう。

\section{選抜の方向とその関連事項}

近年普及してきた深耕用の二段耕犁は， $75 \mathrm{~kg}$ 内外の抵 抗をもつものと考光られるので, ての方面からは役力の 堌大が強了要望されている。しかし使役の程度は相変ら ず短い農繁期にかたよつて，遊休期間が長く，そのため 飞役畜の改良は著しい制約をうける。とてろで最近にお ける食肉の需要增加は, 役畜の肉畜化を要望する状勢に なりつつある。従来純役畜と考えられてきた馬について さえも, ある程度肉的価值を考虑にいれる必要があると いわれるくらいであるから, 役肉牛といわれてきた和牛

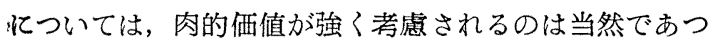
て, 全国和牛登録協会及び日本褐毛和牛登録協会が, 19 57年度になつて相ついで審査標準の改訂を行つたのは,
ての状勢を充分に䓔虑したてとにも起因している。この 場合役用体型と肉用体型とがどのような関係にあるかと いう問題を一応検討してみる必要がある。とてろが肉用 体型について多数の材料を用いた研究は, 以外にも日本 にはほとんどなく，従来の所論には経験論が多かつたよ うである。そてで米国で最近相ついで行われた Coor et al. (1951) ${ }^{29}$, White and Green (1952) ${ }^{30)}$, YAO

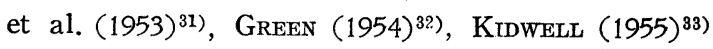
などの研究報告を参照すると，体幅とくに前躯の幅があ つて, 後躯と腿とが充実し, 体高は高くなく, 管は太く なく，体長は長くないととが，肉用として望ましい体 型とされている。ところが従来の観念で役用体型と考え られてきたのは, 前勝で, 深さはあつても幅のない, 骨 が太くて肢はむしろ長いものであつたようであるから， ての観念にてだわると, 肉用体型とは明かに相反する点 が多く, 両者の調和にかなり困難が伴うわけである。然 るにさきに紹介した岡本等 $\left.(1955)^{12}\right)(1956)^{13)}$ が重率引に 適する体型と結論したものを考慮すると，体長の点では 多少の問題があるが，その他の点については肉用体型と ほとんど矛眉しないことがわかる。褐毛和牛の審査標準 は, ての事実を念頭において, 時代の要望に添うように 改訂された。なおての間の事情については岡本(1957) ${ }^{34)}$ の別の総説を参照されたい。

以上のように役畜の肉畜化が選抜方針として取上げら れるとすれば，発育の問題が切実な問題になるが，熊崎 等 $(1955)^{35}$ によると, 黒毛和牛の発育率は最近かなり向 上しているらしい。もつともてれには改良効果だけでな 々, 餇養管理の改善も関係しているであろう。一方肉牛 の発育に関する統計遺伝学的研究が, 最近米国ではかな り活発であつて, KNAPP and NoRDSKOG(1946) ${ }^{36)}, \mathrm{KN}_{\mathrm{N}}$ APP et al. (1950) ${ }^{37)}$, Кoch and CLARK(1955) ${ }^{38)}$, RoLLINS and WAGNON (1956) $\left.{ }^{39}\right)$ などによつて, 生時体重, 増体率, 飼料の効率, 及びその他発育に関係する二三の 特貿について，かなり高い遺伝力が推定されている。日 本でも熊崎等(1956) $\left.{ }^{40}\right)$ がこの種の研究を取上げたのは喜 ばしいととである。

一般に体型の遺伝については，日本でも研究が可能で あるから，もつと活発に取上げたよいはずである。そう しないとせつかく進んできた体型と能力との関係に関す る研究が, 選拔面に充分には活きててないととになる。

\section{結語}

本稿は役畜を対象とする最近の研究のうち, 選抜に関 係の深いものだけについて紹介したものである。従つて 畜力一般の問題としては重要な多くの研究があつてもと 
てではふれなかつた。なお研究の目的は本稿の趣旨と違 つているが，最近藤村 $(1956)^{41}$ )がその輓曳理論に関する 研究において，かなり独創性の高い結論を述へ，その中 で多少役畜の体型にもふれているので, 是否の論はとも かくとして, 最後につけ加えて各位の御検討を望みた い。

\section{文献}

1）岡部利雄 日畜会報, $25(2 \sim 4): 32,1954$.

2）岡部利雄 畜産学の進歩, 384, 1956.

3）羽部義孝 植物及び動物, $11(8,9,10), 1943$.

4) 羽部義孝 牛の役利用に関する研究, 畜産技術 協会, 東京, 1946 .

5）石崎三郎 畜力利用研究会誌, 2 20, 1956.

6）石原盛衛・吉田武紀・羽部義孝・上坂章次 中 国四国農試報告, B $1: 1,1952$.

7）石原盛衛・吉田武紀 中国四国農試報告, B 2 : 49, 1952 .

8）、石崎三郎・篠原旭男・本沢昌一 日畜会報, 20 : 92, 1949.

9）石崎三郎・本沢昌一・篠原旭男 関東々山農試 報告, $2: 86,1951$.

10）石崎三郎・本沢昌一 - 小山錦也 同, 5:87, 1954.

11）石崎三郎・本沢昌一・篠原旭男 - 小山錦也 日 畜会報，25(2～4)：168，1954.

12）岡本正幹・伊東祐之・黑肥地一郎鹿大農学部 学術報告, $4: 1,1955$.

13）岡本正幹 - 大坪孝雄 - 小川清彦・堌満洲市郎 同, $5: 41,1956$.

14）黒肥地一郎・木村貞夫・美濃貞次郎 - 石井尚一 九州農試畜産部試験成績, 昭 $28: 26,1954$.

15）石原盛衛・吉田武紀・高増克三 中国農試報告 B5 : 49, 1956.

16）石崎三郎・本沢昌一・篠原旭男 - 小山錦也 - 中野 優 関東々山農試報告, $4: 118,1953$.

17) KrÜGER, L. und G. SeEFELdt $Z$ Z. f. Tierzücht. u. Zücht. Biol., $64: 175,1955$.

18) SAGHiN, I., I. Mator and A. Popa A. B. A., $25: 23,1957$. (抄録)

19) Prawochenski, R. and W. Piotraszewski Ibid., $22: 22,1954$ (抄録)
20) Prawochenski, R. and W. Piotraszewski Ibid, . $23: 254,1955$ (抄録)

21) Wenger, $H$. Untersuchungen über die Arbeitleistung von schweizer Rindern. Diss. Zürich, 1939.

22）小田良助 - 石橋貞人 - 河田喬 山口大農学部学 術報告, 4:1，1953.

23）石原盛衛・吉田武紀 中国農試報告, B5：37, 1956.

24）岡本正幹・大坪孝雄 - 石神信男 日畜会報, 25 , (2 4) : 163, 1954.

25）岡本正幹・大坪孝雄・小川清彦・田代一男 同, $27: 223,1956$.

26）富永信 - 高橋久男 - 高橋英伍 - 木下善之 ・ 渡辺昭 三・村田和子・浅井豉太郎日畜会報, 28 (別) $: 45$, 1957.

27）野田真五郎・中野優関東々山農試報告，2： 96, 1951 .

28）野田真五郎 -中野優 同，4:129，1953.

29) Соок, A.C., M.L. Kohlr and W. M. Dawson J. Anim. Sci., $10: 386,1951$.

30) White, F. E. and W. W. Green Ibid., $11: 61,1952$.

31) Yao, T. S., W. M. Dawson and A. C. Cook Ibid., $12: 775,1953$.

32) Green, W. W. Ibid., 13:61, 1954.

33) KIDWELL, J. F. Ibid., $14: 233,1955$.

34）岡本正幹畜力利用研究会誌., 3 ：，1957.

35）熊崎一雄 - 田中英治 - 木原靖博中国農試報告 B 4: 73, 1955.

36) Knapp, B. and A. W. Nordskog J. Anim. Sci., 5 : 62, Ibid.. 5: 194, 1946.

37) Knapp, B. and R. T. ClaArK Ibid., 9:58 2, 1950.

38) КосH, R. M. and R. T, CLARK Ibid., 14 :775, Ibid., $14: 786,1955$.

39) Roluins, W. C. and K. A. Wagnon Ibid., 15:125, Ibid., 15:529, 1956.

40）熊崎一雄 - 田中英治・木原嗉博中国農試報告, B 5 : 57, 1956.

41）藤村忠明 山口大農学部学術報告, $7: 447,19$ 56. 